\title{
International Rain-forest Project Launched at Britain's Royal Geographical Society
}

As many as 10 million species of plants and animals mainly insects - are still waiting to be discovered by Mankind, claim scientists who expect to find some of them in the rain-forests of Brunei. Insect biodiversity is one of the central themes of an international rain-forest project to help establish a Field Studies Centre in the undisturbed forests of the Temburong District of the Sultanate of Brunei.

Discoveries of new species during the project are likely to be dominated by insects. Dr Nigel Stork, head of insect biodiversity at the British Museum (Natural History) in London and one of the project's scientific supervisors, has some idea of what lies in store. During a previous expedition to Brunei he found 400 species of beetle in just one tree! 'Scientists have described 1.5 million living species in the world so far', he said, 'but recent estimates suggest there may be up to 10 millions more.'

The Field Studies Centre is currently being built by the recently-founded University of Brunei Darussalam (UBD). It will give the University an essential base for teaching and research, and rain-forest conservationists hope it will help to boost the status of biology and conservation in the region. Brunei's High Commissioner in London, H.E. Pengiran Mustapha Metassim, was present at the launching of the Brunei Rain-forest Project recently at the headquarters of the Royal Geographical Society in London. The Prince of Wales is Patron of the Project, which is being organized by the Royal Geographical
Society at the invitation of the UBD. Led by Lord Cranbrook, an experienced rain-forest biologist and future chairman of the reorganized Nature Conservancy Council for England, the first group of scientists are arriving in Brunei in January 1991.

A core team of scientists will work in the forest for more than a year, collecting baseline data for the new Field Studies Centre. Research plans are already being drawn up by the Natural Environment Research Council and the British Museum (Natural History). They will focus on insect biodiversity, plant surveys, and the forest's hydrological cycle. A further 40 scientists and students will carry out shorter projects during the same period.

Free from the effects of logging and human settlement, the research area is far from human disturbance. Tests will show if distant sources of pollution have affected air and water quality in the undisturbed forest. 'With this Centre, Brunei can contribute to a better world understanding of some of the more important global problems', said Lord Cranbrook, Leader of the Project. For further details please contact either of the undersigned.

Deborah Macklin \& Catriona Prebble Royal Geographical Society

1 Kensington Gore

London SW7 2AR

England, UK.

\section{World-wide Automotive Revolution Needed to Protect Earth's Atmosphere}

The explosive growth of the world's motor-vehicle fleet makes sweeping technological changes - including 'green' cars that do not use fossil fuels or pollute otherwise - crucial for reducing the risks of damaging the atmosphere and importing oil from volatile regions such as the Persian Gulf, a new report from the World Resources Institute (WRI) concludes.

The disruption of world oil-supplies in the wake of Iraq's invasion of Kuwait is only the latest reminder of how tightly transportation is linked to many nations' economic and national security. Cars and trucks - powered almost universally by oil - account for one-third of the world's petroleum consumption. In the industrialized countries, motor vehicles account for more than $40 \%$ of oil demand, and in the United States over 50\%. Moreover the heavy reliance on oil from the Middle East is growing.

According to Driving Forces: Motor Vehicle Trends and Their Implications for Global Warming, Energy Strategies, and Transportation Planning, by WRI Senior Associate James MacKenzie and transportation expert Michael Walsh, the global motor-vehicle population could easily double over the next twenty years, thereby cancelling out any likely gains there may be in fuel efficiency and pollution emissions. A transition to virtually pollution-free electric and hydrogen-powered vehicles is necessary to reduce the threats of global warming and dependence on imported oil.

'Close to one [thousand million] motor vehicles will be in use by early in the next century, twice the 540 million cars, trucks, buses, and commercial vehicles, in the world today,' forecast MacKenzie \& Walsh. 'Environ- mental threats to the atmosphere - climate change, depletion of the stratospheric ozone layer, acid rain, and urban smog - are exacerbated by gasoline and dieselpowered motor vehicles. Global efforts to reduce vehicle pollution and improve fuel efficiency can limit the damage in the near term, but if the number of vehicles and [distances] driven continue to grow at today's rates, such progress will be overwhelmed.'

The report offers key recommendations to reduce transportation's effect on climate change and dependence on foreign oil. For the long term, nothing less than creation of a 'green car' for the future will do. Although technical improvements in petroleum-powered vehicles can help in the short term, ultimately the world needs non-polluting vehicles that run on something other than fossil fuels. Mercedes Benz and BMW have already produced hydrogen-powered vehicles for research, and General Motors is now selling an electric van. The Authors caution, however, that electricity and hydrogen for pollution-free vehicles should ultimately be provided by such non-fossil energy technologies as solar cells and wind turbines.

For the short term, the report calls for a concerted effort by the United States and other leading industrialized countries to:

- Improve new-vehicle efficiency and phase out older, less efficient cars and trucks. Much of the technology needed to produce more efficient vehicles has already been demonstrated in ultra-efficient 'concept' cars that get up to 100 miles per gallon $(100 \mathrm{~km}$ on 2.35 litres) of gasoline.

- Make transportation more efficient, convenient, and affordable. Policies that encourage commuters to use 